\title{
Translation of the Holy Quran: A Call for Standardization
}

\author{
Ahmad Mustafa Halimah \\ Department of English Language \& Literature \\ College of Arts, King Faisal University \\ P. O. Box 1759, AlAhsa 31982 \\ Kingdom of Saudi Arabia \\ E-mail: Drhalimah@aol.com
}

Doi:10.7575/aiac.alls.v.5n.1p.122

Received: 02/01/2014

URL: http://dx.doi.org/10.7575/aiac.alls.v.5n.1p.122

Accepted: 28/02/2014

\begin{abstract}
The recent increase in the number of English translations of the Quran has led to problematic misrepresentations, misinterpretations and even textual discrepancies in the translations of a number of Islamic concepts, principles and norms. This paper is an attempt to evaluate five different English versions of the translation of the Quran using concepts, principles and norms as parameters for discussion and analysis. Results of discussion and analysis of the samples used in this paper have indicated that there is an un urgent need for a mechanism that will help using the formation of a standardised version of an explanatory translation of the meanings of the Quran that is authoritative in form and content to be used all over the English Speaking world. To achieve this objective, a list of suggestions and recommendations have been made for use by those in authority and for those who are interested in carrying out further research in this field.
\end{abstract}

Keywords: Quran, translation, interpretative, authoritative, misrepresentation, standardization

\section{Introduction}

Interest in the translation of the Quran has grown steadily since the first translation rendered into English by Alexander Ross in 1649, followed by the translations of George Sales in 1734, J. M. Rodwell in 1861, M. Pickthall in 1930 and then by A. Y Ali in 1934. (Al- Shabab, 2008, 2012; Mustafa, 2011). This paper focuses on five translations selected from a corpus of translations made in early 20th century onwards, mainly translations of Ali, A Y (1934,1977) An Indian Muslim, Arberry, A. J (1955, 1988) an English Christian, Dawood, N.J. (1956,1974) an Arab Iraqi Jew, AbdelHaleem, M (2004,2010) an Arab Egyptian Muslim, Yuksel. E, Al-Shaiban L and Schult-Nafeh (2007,2010) A Turkish Kurdish Muslim.

Although there have been several studies of the translation of the Quran (Versteegh, 1991, Bobzin 1993, Abdul-Raof, 2001a, 2005, AlShabab, 2008, 2012, Mustafa, 2011), the issue of standardising the translation of the Quran into English has not been raised in terms of finding a profiling mechanism that translators can use in translating conceptual premises. This article will question the worthiness of having multiple translations of the Quran and will argue the case for a standardised translation of the Quran.

It is unfortunate that there is now a multitude of Quranic Translations being used at the moment. This is bound to give rise to distorted conceptions and perceptions and even misunderstanding of the original text by Muslims or nonMuslims. The translation of the Bible, for example, followed a certain progression manner from an initial diversity of translations to the emergence of a fixed authoritative text (Long, 2001, Serban, 2005). This authoritative text of the Bible seems to have successfully unified Christians around one single reference version in case of dispute over principal concepts or issues in Christianity as a religion of over more than a billion people. Therefore, there is an urgent need for a single standardised English Translation of the Quran to be used by all or at least by the majority of English Speaking Muslims.

\section{Theoretical Considerations}

Translation strategies throughout history could be dichotomised as being one of each of the following five pairs: literal vs. free, formal correspondence vs. dynamic equivalence, foreignising vs. domesticating, direct translation vs. indirect translation, and communicative vs. semantic translation. Ultimately it has been argued that "full authenticity and communicative clarity cannot both be achieved' (Kirk, 2005, p99) in religious texts, as is the case in translating the Quran, as the source and target languages and cultures are very different. A choice then must be made between meeting the linguistic and cultural expectations of the Target Language (TL) reader and satisfying his/her taste/ and on one hand and violating the main theological concepts of the text on the other. 
A suitable approach to looking into the problems arising from the dispersions of so many translations of the Quran is a hermeneutic approach as this would give us the ability to compare how translators use their exegetical tools for understanding and interpretation be they linguistic, cultural, conceptual, psychological, theological or spiritual.

Hermeneutic approaches have been used in translation studies for a very long time. Hermans $(2011,130)$ presents a detailed overview of hermeneutics chronologically from the days of the ancient Greek god Hermes who used to translate the messages between the gods and the mortals. In other words, translation could be looked at as an act of interpretation based on the hermeneutic framework. It means to 'to interpret, explain, narrate, clarify, translate.'

Al-Shabab (1996, 2008) has extensively argued that translation is merely an 'an interpretative (hermeneutic) behaviour'. He also suggests that this interpretive nature of translation is bound to give rise to 'differences' in translation (Al-Shabbab, 1998).

Delisle, Jean (1988:53-6) focuses on the cognitive element in the translation process as he views it as a heuristic process of critical discourse analysis which goes through three stages: comprehension of the signs of the Source Text, reformulation of the concepts of the source utterances by means of the signifiers of another languages and then the verification stage which involves a comparison between the original and its translation.

O'Donnell (2004, p. 165) also states that 'every translation is an interpretation, and therefore, even when making a quick initial translation, the exegete is forced to make interpretative decisions'. He concludes that through the use of interpretative translation one can communicate the overall understanding message of a sacred text without resorting to the use of 'verse -by-verse comments'.

Serban (2005) argues that 'archaising' and 'modernising' can be used as stylistic strategies in translating religious texts as they can serve different purposes and different target audience. The former highlights the historical association and mystery of the religious expression and the latter uses the contemporary language.

As for Salama-Carr, M (2011, p.146), translation is seen as 'a dynamic process of comprehension and re-expression of ideas'.

In the translation of the Quran in particular, Abdel Haleem (2011, p.67) states that we should 'aim for an explanatory translation of the meaning. The oddities we have in many English translations result from excessive literalism and adherence to the syntactical and stylistic peculiarities for the Arabic language and the language of the Quran, which is very concise, idiomatic, figurative and elliptic'.

Having made those references and being a practitioner interested mainly in the translation product of the Quran, I am tempted to adopt a product interpretive approach to translation loaded with constraints of the theological norms of the faith carried in the text. In other words, any interpretative translation of the meanings of the Quran is accepted if it does not violate any of the principal theological concepts or norms of the faith and it is rejected if it does. To achieve such acceptable version of the Quran in English, the translated text should achieve maximum approximation in equivalence and the communicative purpose of the text should be conveyed in an appropriate style without violating any theological concepts, principles or norms held by the faith. A Translation of this standard should obviously endeavour to transfer into English the linguistic, social, cultural and religious associations and connotations of the original text, in addition to its rhythmic and rhyming impact on the TL reader or receptor, if possible.

\section{The scope of this study}

Guided by the theoretical background of the study, the major aim of this article is to investigate a number of problems, difficulties and pitfalls the translators of the Holy Quran tend to face when translating Quranic concepts that lack counterparts in the English language and culture. This will be achieved by using excerpts taken from the following five different English versions of the Quran as they represent samples of translations made by different translators who belong to different periods of time and linguistic, cultural, religious, theological and even ideological backgrounds. This diversity in background is bound to have had some repercussions on their translations. These translations are:

1. Ali, A Y $(1934,1977)$ An Indian Muslim

2. Arberry, A. J $(1955,1988)$ an English Christian

3. Dawood, N.J. $(1956,1974)$ an Arab Iraqi Jew.

4. Abdel-Haleem, M (2004) an Arab Egyptian Muslim.

5. Yuksel. E, Al-Shaiban L and Schult-Nafeh $(2007,2010)$ A Turkish Kurdish Muslim

It is hoped that this study will provide useful information for English Speaking Muslims and non-Muslims interested in reading the meanings of the Quran in English and for academic institutions and translators with regards to the following:

A. The need to establish one single Authority which would standardise and authorise one single translation of the Quran.

B. Any translation of the Quran should presuppose its importance for the community of faith, for those who hold the canonical treatment of the text as authoritative for faith and practice. (i.e. Arab Muslims in the main)

C. Guiding Quran Translators to dictionarising and standardising the translation of the theological concepts and principles that lack counterparts in the Target Language. 
This study does not, however, aim at comparing source texts with translated texts comprehensively, but rather comparing different translations of the same text in terms of degree of deviation from the normative understandings and interpretations of the text in question. It is not considered to be an exhaustive study but rather an endeavour to draw attention to the phenomenon of translating the Quran without a necessity.

\section{The Quran as Central Text}

It seems that every new Quranic translation has its own explanation and justification for its appearance. It tries to position itself as the fulfilment of what the Source Language (SL), Arabic really meant to express.

Ali's version (1934) claims that his translation came as a result of poor translations made by scholars such as George sale's (1734), J. M. Rodwell (1861) E.H Palmer's (1876) and an urgent need and demand for a translation made by a Muslim scholar. The importance of the English language and its impact in the world was an impetus to spread the thought and intellect of the Quran to the whole world. He also claims that although Pickthall was an English Muslim and a man of literary standing, his translation was 'almost literal' and lacked sufficient notes to elucidate the text. That is why he took up this project and decided to make up for all the demerits and shortcomings the translations of his predecessors suffered from.

Arberry's version (1955) seems to have concentrated on improving the performance of his predecessors in achieving the 'the sublime rhetoric of the Arabic Quran. He emphasises the rhythmic product of the translation more than the message itself. This unbalanced emphasis may have unintentionally made him commit some principal errors in the translation of certain vital Islamic concepts (see below for more details). For him the sounds and the rhythmic effect of the verse are of paramount importance, since they could enable the English reader to enjoy the same emotive and psychological experiences enjoyed by the Arabic reader.

Dawood's version (1956) claims to have presented the modern reader with an intelligible version of the Quran in contemporary English in spite of the fact that he abandons the traditional arrangement of the chronological order of the Suras or chapters but rather follows a more biblical and poetic arrangement, which he claims is intended for the 'uninitiated reader who is often put off by such mundane chapters as the 'cow' or the 'Table' which are traditionally placed at the beginning of the book. This irresponsible attitude towards the sacredness of the form and content of the original text seems to have spilled over and to have been negatively reflected in his translation of a number of Islamic concepts as will be explained below.

Abdel Haleem's version (2004) is another attempt made by an Arab Muslim to make the Quran accessible to everyone who speaks English, Muslim or otherwise, claiming that it is unlike previous works in the sense that it is more accurate, clearer and easier to read. However, is accuracy or clarity justifiable when it causes mistranslation or misinterpretation of main concepts and canons of faith?

As for the translation of Yuksel. E, Al-Shaiban L and Schult-Nafeh $(2007,2010)$, it is they claim a reformist translation in the sense that it rejects the Hadiths of the Prophet Muhammad (pbbuh) as a source of religious law and guidance in understanding and interpreting the message of Islam revealed in the Quran. This is reflected in their approach to the translation of the meanings of the Quran.

No matter what the motives for the translations may have been, any translation of the Quran should presuppose its importance for the community of faith, for those who hold the canonical treatment of the text as authoritative for faith and practice. In addition, it is imperative that the translator's own underlying ideological and theological beliefs be prevented from interfering not only in the process of translation but from misinterpreting and construing the rendered text. The discussion below will reflect this state of affairs.

\subsection{From a legislative perspective}

Needless to say, the most authoritative source of the Islamic law is the Quran. It is the Word of Allah revealed to Muhammad (p.b.b.u.h) through Angel Gabriel, over a period of twenty-three years. Since it was revealed to Muhammad (p.b.b.u.h), the Last Messenger of Allah (p.b.b.u.h), and as no corruption of whatever kind has ever occurred to it, neither in its content nor in its form it stands as proof that it has been guarded by Allah who Himself sent it down to all Mankind and undertaken to keep it as pure as when it was revealed. Allah (SW) said:

$$
\text { "إِنا نحن نَزَّلنا الأذّكرَ وَإِنا له لحافِظون " [سورة الحجر : }
$$

"We have, without doubt, sent down the Message; and We will assuredly guard it (from corruption)." (S.15, A.9)

Therefore, the Quran is considered not only an absolute authority in Islam but it is also viewed as the most sacred, most valuable and most dear to Muslims.

Undoubtedly, the single most important text in Islam is the Quran itself. So central is the Quran to the Arabic and Islamic culture as a whole that scarcely any account of the latter can afford to overlook the importance and impact of the Quran.

It is vital to recognise that the majority of English speaking non-Muslims in general and Muslims in particular read the Quran as an authoritative religious text, a practical guide to life and not as literary pieces of writing. Therefore, no translation could afford an error in translating principal theological concepts as it might backfire theologically and ideologically. 
The Quran is a sacred revelation from Allah the Almighty to Prophet Muhammad (PBBUH). It is divine in source and human in practice. Its translation should reflect these two important features.

\subsection{From a linguistic/stylistic perspective}

Hatim and Mason (1990:69) define genre as "conventionalised forms of texts" which reflect the functions and goals involved in particular social occasions as well as the purposes of the participants in them". However more subjective, less institutionalised and much vaguer classifications seem to have been used to describe texts as wholes or parts of them such as 'narrative', 'expository', 'argumentative' and 'instructional' texts (Baker, 2011).

As for the genre of the Quran, Arberry (1988, px) describes the style of the Quran as 'neither prose nor poetry, but a unique fusion of both.' In this respect, I would say that one of the prodigies of the Quran is its matchless discourse and rhetorical style. The style of the Quran doesn't belong to any type of literary texts or genres, be it poetry, prose, drama or any other narrative style but it has its own miraculous and idiosyncratic style which would make one feel that they are simultaneously in front of a multi-type text; a narrative text on one occasion, a descriptive dialogue on another and an impressive text on a different occasion; nevertheless the Quran is neither of them when it is looked at as one complete distinctive style that has its own eloquence, diction, intensity and variety of expressions. In other words, the style of the Quran is like no other style as it combines miraculous expressive rhetoric and discourse on the one hand and prodigious past and unseen future events for each of which there is evidence in the Quran on the other hand. And this is what makes the Quranic text a potential trap for translators to fall in.

\section{The Translation of the Quran}

Since the revelation of the Holy Quran in 612AD, scholars from different fields have been trying to solve the controversy of translatability of the Quran. Orthodox Muslim scholars claim that since the Quran is the Word of Allah, it is 'untranslatable'; whereas a number of Muslim and non-Muslim scholars claim the opposite.

No doubt at all, the meanings and/or 'tafseer' -interpretation- of the Quran has been translated into many different languages such as Persian, Turkish, Urdu, French, German, English and many others. What concerns us here is the English versions of the Quran 'Tafseer' being widely spread all over the world. The Quran has been transferred into English by scholars who speak different languages, belong to different religions and hold different ideological and theological views. This has definitely, whether consciously or unconsciously, intentionally or unintentionally influenced the product of its translation. Although these scholars were apparently competent in Arabic, the language of the Quran, they lacked the ability not only to have the 'feel and spirit' of the Quranic word, but also to recognise the linguistic and cultural dimensions of it.

\section{Discussion of Sample Comparisons}

To investigate the issue more profoundly, an attempt will be made to discuss it from different perspectives. Sample comparisons will be used to verify that differences in translating the Quranic original text have led to misinterpretations and misconceptions of a number of Islamic concepts and principles. Examples from each version are given and discussed mainly from a linguistic and cultural perspective with occasional reference to rhetorical, psychological and melodic features.

\subsection{The Translations of the Quran from a linguistic perspective}

The following example gives us material through which to look at the significance of the 'lexical meaning of a word' and the importance of 'word order' as one of the major grammatical categories of difficulties translators encounter in translation. For instance, unlike English, Arabic doesn't tend to have a fixed word order because it has an elaborated case inflection and due to different stylistic variations (Baker, 2011). A change in 'word order' may cause both message incoherence and a theological disorientation.

Example Passage 1: Quran (24:2)

$$
\text { "الز انية والزاني فاجلدوا كل واحدٍ منهما مائة جلدة" (سورة النور : آية 2) }
$$

'alzaniyatu wa alzani fajlidu kul wahidin minhuma maata jalda'

\begin{tabular}{|l|l|l|l|l|}
\hline \multicolumn{1}{|c|}{ Yusuf Ali (1934) } & \multicolumn{1}{|c|}{ Arberry(1955) } & Dawood (1956) & Abdel Haleem (2004) & Yuksel etal (2007) \\
\hline $\begin{array}{l}\text { The woman and the } \\
\text { man guilty of } \\
\text { adultery or } \\
\text { fornication, - flog } \\
\text { each of them with a } \\
\text { hundred stripes. }\end{array}$ & $\begin{array}{l}\text { The fornicatress } \\
\text { and fornicator- } \\
\text { scourge each one of } \\
\text { them a hundred } \\
\text { stripes. }\end{array}$ & $\begin{array}{l}\text { The adulterer and } \\
\text { the adulteress } \\
\text { shall each be } \\
\text { given a hundred } \\
\text { lashes. }\end{array}$ & $\begin{array}{l}\text { Strike the adulteress } \\
\text { and the adulterer one } \\
\text { hundred times. }\end{array}$ & $\begin{array}{l}\text { The adulteress } \\
\text { and the adulterer, } \\
\text { you shall lash each } \\
\text { of them one } \\
\text { hundred lashes. }\end{array}$ \\
\hline
\end{tabular}


Although the above example is void of any metaphor, the translators seem to have made serious mistakes as a result of their inability not only to find the right meaningful equivalent of the word but to also understand the significance of the word order in the Quran as a whole.

At the word level, the Arabic verb 'fajlidu' has been translated by them as 'flog', 'scourge' 'give a lash', 'strike' and 'lash' respectively. The four different translation versions of the Arabic verb 'fajlidu' show that it has no absolute conceptual equivalent in English. To be able to choose the most appropriate equivalent in terms of its semantic connotations, conceptual associations and theological interpretations, ten native speakers of English were asked to rank these words along with the verb 'whip' from 1 to 5 as number (1) indicates the highest degree of 'beating' (i.e. physical harm and severity) and number 5 is the lowest degree of 'beating'.

Looking at the table below, we can see that 9 out of 10 native speakers of English agreed that the verb 'flog' carries the strongest connotation of 'beating', and 9 out of 10 agreed that the verb 'lash' would give the mildest connotation of 'beating', whereas 8 out of 10 agreed that the verb 'scourge' would give a weak connotation of 'beating'. As for the verb 'strike', 7 out of 10 agreed that it would give a rather weak connotation of 'beating'. Respondents seemed to be indecisive about the verb 'whip' as they split in opinion into 4 indicating strong connotations and 4 indicating weak connotations and 2 out of 10 said it could give a mild connotation. This could be a reason as to why the translators avoided using it.

Semantic connotations of the 'beating' verbs

$$
\text { as being 'Strong', 'Mild' 'Weak' }
$$

\begin{tabular}{|l|l|l|l|l|l|l|}
\hline & S & & M & & W & \\
\hline Words & $\mathbf{1}$ & $\mathbf{2}$ & $\mathbf{3}$ & $\mathbf{4}$ & $\mathbf{5}$ & Total \\
\hline Flog & 7 & 2 & & 1 & & 10 \\
\hline Lash & & 1 & 7 & 2 & & 10 \\
\hline Scourge & 1 & 1 & & 1 & 7 & 10 \\
\hline Strike & 1 & 1 & 1 & 3 & 4 & 10 \\
\hline Whip & & 4 & 2 & 4 & & 10 \\
\hline
\end{tabular}

They could be semantically ranked as follows:

1. Flog with a hundred stripes $>$ strongest connotations (Ali's)

2. Give a hundred lashes $>$ mild connotations (Dawood's) Lash one hundred lashes $>$ mild connotations (Yuksel's)

3. Scourge with a hundred stripes $>$ weak connotation (Arberry's)

4. Strike one hundred times $>$ weak connotation (Abdel Haleem's)

5. Whip one hundred times $>$ indecisive connotation (not used)

The semantic connotations of the Arabic verb 'fajlidu' seems to prefer the verb 'lash' to the others as the whole idea behind this kind of punishment is not to physically cause severe pain to the sinful but rather to psychologically and morally humiliate him or her and make him or her suffer and repent. This is supported by the way the 'lashing' is carried out mainly on the back of the sinner avoiding sensitive areas of the body, which should be mildly done, neither severely nor lightly, taking into account certain legislative constraints such as the main purpose of applying the 'lashing', the instrument used (i.e. type and nature of the whip), how to use the 'whip' (i.e. the position and movement of the arm used to lash the sinful). Therefore, I would standardise it by using the verb 'lash' as its semantic connotations, conceptual associations, theological interpretations, and the spirit of Islam tend to determine this choice.

As far as the word order is concerned, it is very important to note that although Arabic unlike English is a highly inflected language and one can manipulate the word order in Arabic more flexibly, one cannot manipulate -in most cases-the word order followed in the Quran because it has its own significance. In the above example, we can see that Dawood has violated a philosophical and religious principle in Islam by putting in his translation of 'azzaniyatu wa azzani' - the male before the female. It is the only place in the Quran that the female is mentioned before the male. It is to add that it is the woman who tends to be responsible when an illegal sexual intercourse takes place whether before or after marriage. If the sexual intercourse took place without the prior consent of the woman, then the whole act would not be called an 'adultery' or 'fornication', but rather 'rape'. Therefore, the translator should pay a special attention to such implications for the translation of word order in Arabic and not to be deceived by certain norms of the language.

One more example in this respect will reinforce the need to standardise certain terms and concepts in the translation of the Quran as such unnecessary differences in translation tend to cause not only misinterpretations but also misconceptions of Islam as a religion or 'way of life'. 


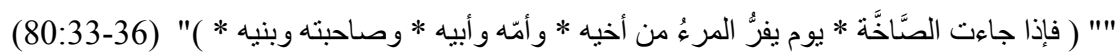

'fa iza jaat issakha, Yuma yafiru lmaro min akheeh, wa umihi wa abeeh, wa sahibatihi wa baneeh'

\begin{tabular}{|c|c|c|c|c|}
\hline Yusuf Ali (1934) & Arberry(1955) & Dawood (1956) & Abdel Haleem (2004) & Yuksel etal(2007) \\
\hline $\begin{array}{l}\text { "At length, when } \\
\text { there comes the } \\
\text { Deafening Noise, } \\
\text { that day shall a man } \\
\text { flee from his own } \\
\text { brother, and from } \\
\text { his mother and his } \\
\text { father, and from his } \\
\text { wife and his } \\
\text { children," }\end{array}$ & $\begin{array}{l}\text { "And when the } \\
\text { blast shall sound, } \\
\text { upon the day when } \\
\text { a man shall flee } \\
\text { from his brother, } \\
\text { his mother, his } \\
\text { father, his consort, } \\
\text { his sons," }\end{array}$ & $\begin{array}{l}\text { "But when the } \\
\text { dread blast is } \\
\text { sounded, on that } \\
\text { day each man } \\
\text { will forsake his } \\
\text { brother, his } \\
\text { mother and his } \\
\text { father, his wife } \\
\text { and his } \\
\text { children;" }\end{array}$ & $\begin{array}{l}\text { When the Deafening } \\
\text { Blast comes the Day } \\
\text { man will flee from his } \\
\text { own brother, his } \\
\text { mother, his father, his } \\
\text { wife, his children: } \\
\text { each of them will be } \\
\text { absorbed in concerns } \\
\text { of their own on that } \\
\text { Day. }\end{array}$ & $\begin{array}{l}\text { "So when the } \\
\text { screaming shout } \\
\text { comes, the day } \\
\text { when a person will } \\
\text { run from his } \\
\text { brother. His mother } \\
\text { and father. His } \\
\text { mate and } \\
\text { children." }\end{array}$ \\
\hline
\end{tabular}

Variations in translating the above passage have evidently given rise to problems in rendering the right equivalence, achieving the communicative purpose of the message and failing to achieve any degree of the stylistic features expressed in the verse. The wrongly chosen words for 'wa sahebatehi wa baneeh' 'wife/consort/mate' and 'children/sons' respectively tend to cause misrepresentation of what is really meant in the Arabic text. As for the word 'sahibatihi', Arberry and Yuksel etal. have wrongly translated it as the concept in Arabic means a 'wife' whereas the propositional meanings of the words 'consort' or 'mate' don't really mean a 'wife' but they could have multiple meanings as follows:

Consort: partner, companion, husband, wife, comrade,

Mate: companion, comrade, fellow, friend, hubby, husband, masculine, associate,

Furthermore, Arberry seems to misunderstand the meaning of 'baneehi' which simply means children, both boys and girls, not only sons.

The above brief discussion leads us to confirm our need for standardising such terms or concepts so that one single message rather than a double or multifaceted message is retranslated into to English.

\subsection{The Translations of the Quran from a cultural perspective}

One of the major difficulties translators encounter in translating religious texts is the translation of theological concepts that lack a counterpart in the target language. This could be due to the problem of cross-cultural interpretations. The following example illustrates the nature of the problem that faced the afore-mentioned translators of the Quran when they failed to capture the theological dimension and cultural and social connotations of the concept of 'adultery' in Islam.

Example Passage 3: Quran (17:32)

"و لا تقربوا الزنى أنه كان فاحشة وساء سبيلا" (سورة الإسراء: آية 32)

'wa la taqrabu azzina inahu kana faheshatan wa saa sabeela'

\begin{tabular}{|l|l|l|l|l|}
\hline \multicolumn{1}{|c|}{ Yusuf Ali (1934) } & \multicolumn{1}{|c|}{ Arberry (1955) } & Dawood (1956) & Abdel Haleem (2004) & Yuksel etal(2007) \\
\hline $\begin{array}{l}\text { Nor come nigh to } \\
\text { adultery; for it is a } \\
\text { shameful (deed) } \\
\text { and an evil, opening } \\
\text { the road (to other } \\
\text { evils) }\end{array}$ & $\begin{array}{l}\text { "And approach not } \\
\text { fornication; surely } \\
\text { it is andecency, } \\
\text { and evil as a way" }\end{array}$ & $\begin{array}{l}\text { "You shall not } \\
\text { commit adultery, } \\
\text { for it is foul and } \\
\text { indecent" }\end{array}$ & $\begin{array}{l}\text { And do not go } \\
\text { anywhere near } \\
\text { adultery: it is an } \\
\text { outrage, and an evil } \\
\text { path. }\end{array}$ & $\begin{array}{l}\text { "Do not go near } \\
\text { adultery, for it is a } \\
\text { sind an evil path" } \\
\text { ura 17:32) }\end{array}$ \\
\hline
\end{tabular}

\section{Discussion}

Unfortunately, the five versions clearly violate the Islamic concept of 'adultery'. Ali's Dawood's , Abdel Haleem's, Yuksel etal's versions would mean to an English reader that it is prohibited to practise illegal sex only after marriage; whereas Arberry's version would mean that it is prohibited to practise illegal sex only before marriage. According to western culture, it is socially and culturally acceptable to practise sex before marriage but not after marriage. It seems that their English versions have given a much distorted picture of the Islamic principle which considers sexual intercourse outside of wedlock strictly prohibited, whether before or after marriage. 
As an alternative and standardised equivalent of the concept of 'Azzina', we can suggest the following unit of expression 'adultery or fornication' as it would cover all meanings implied by the Arabic word.

Furthermore, there is a substantial number of theologically culture-specific concepts like ('taqwa= god-fearing, zikr=mentioning of God, assabr=patience, etc...) which require some kind of experiencing on the part of both the translator and the target reader to be able to appreciate the meaning and purpose of the message implied in the translated verse and this state of lack of experiencing has been a serious cause for misinterpretation, mistranslation and consequently misconception of the religious practice of the Islamic concepts. Let's take the following example for our discussion of the question under investigation:

Example Passage 4: Quran (7:26)

$$
\text { "ولباس التقوى ذلك خير" (سورة الأعراف:26) }
$$

'Wa leebasu attaqwa zalika khair'

\begin{tabular}{|l|l|l|l|l|}
\hline Yusuf Ali (1934) & \multicolumn{1}{|c|}{ Arberry(1955) } & Dawood (1956) & Abdel Haleem (2004) & \multicolumn{1}{|c|}{ Yuksel etal(2007) } \\
\hline $\begin{array}{l}\text { But the raiment of } \\
\text { righteousness,- that } \\
\text { is the best. }\end{array}$ & $\begin{array}{l}\text { And the garment } \\
\text { of godfearing- } \\
\text { that is better. }\end{array}$ & $\begin{array}{l}\text { But the finest of } \\
\text { all these is piety. }\end{array}$ & $\begin{array}{l}\text { The garment of God- } \\
\text { consciousness is the } \\
\text { best of all garments_ }\end{array}$ & $\begin{array}{l}\text { And the garment of } \\
\text { awareness is the } \\
\text { best. }\end{array}$ \\
\hline
\end{tabular}

Discussion

Looking at the above versions of the translation of a short part of a verse, one can realize that the differences in the translation have caused linguistic and conceptual mistranslation and even misinterpretation of the Islamic concept in the original text. At the linguistic level, Arberry and Yuksel use the positive connector 'and' whereas Ali and Dawood use the negative coordinator 'but' ('but' is the right meaning here'. Abdel Haleem uses 'zero connector' which causes some kind of serious loss in his translation. At the conceptual level, the concept of 'taqwa' is represented by using different terms for rendering it. Being mainly concerned with concepts here, we could elaborate a bit more about translating technical terms such as 'taqwa' to assert the repercussions of having different translations of the theological concepts in the Quran.

The literal meaning of the word 'taqwa', which relates to 'godfearing, is common knowledge mainly among Arab Muslim. The problem appears when we encounter it as a technical term repeated 84 times in the Quran, as a 'verb' and 9 times as a 'noun'. In either case, it tends to have its own theological but contextually oriented meaning. The above translators seem to have come up with five different translations of this technical term. The most unsatisfactory translation is that of Abdel Haleem's and Yuksel etal's because they used neutral terms without any religious sense and went too far in their misinterpretation of the word 'taqwa' in terms of its contextual and theological meaning, whereas the other three could have come up with one single term as an approximate equivalent to the theological meaning of 'ataqwa' or may have attempted to naturalize it as 'taqwa' (with italics, bold type, or any other kind ) and then explain it in more detail in a footnote.

This technical term is very commonly used among Muslims, especially Arab Muslims and as it has so many contextually constrained meanings, and in the case of the technical term 'taqwa', the translator could make his translation as realistically understood as possible by collecting sufficient information about it but it would nevertheless be short of experiencing the concept of 'tqawa' by his readers. The following is just a short list of English words that could be used to transfer the concept of "taqwa" both as a noun and a verb:

A. God fearing / to fear God or to fear Allah (i.e. to do what brings you closer to Allah and His mercy and to avoid disobeying His orders in fear of His punishment)

B. Righteousness (to do what is right and to avoid doing what is wrong) with God fearing in mind.

C. Piety

D. Piousness

E. Devotion

F. Religiosity

G. Religiousness

As a matter of fact, such theologically and culturally loaded concepts will always be difficult and problematic for the translator and his or her readers because they tend to lack any basis for that concept in their experiences due to belonging to different languages, cultures and even religions. For the translator to be able to translate and his or her readers to grasp and appreciate the translation of such concepts, they both need to have directly experienced the essential meaning and purpose of such concept as 'taqwa'. 


$$
\text { " و الذاكرينَ اللَّهَ كَثِيرًا وَالذاكر ات أَعَدَّ اللَّ لهم مغفرةً و أَجرًا عظيمًا" (سورة الأحز اب:35) }
$$

'Wa adhikreena Allah katheeran wa adhakirat a'ada Allahu lahum maghfiratan wa ajran a 'zima'

\begin{tabular}{|c|c|c|c|c|}
\hline Yusuf Ali (1934) & Arberry(1955) & Dawood (1956) & Abdel Haleem (2004) & Yuksel etal(2007) \\
\hline $\begin{array}{l}\text { For men and women } \\
\text { who engage much } \\
\text { in God's praise,-for } \\
\text { them has God } \\
\text { prepared forgiveness } \\
\text { and great reward. }\end{array}$ & $\begin{array}{l}\text { men and women } \\
\text { who remember } \\
\text { God oft-for them } \\
\text { God has prepared } \\
\text { forgiveness and a } \\
\text { mighty wage. }\end{array}$ & $\begin{array}{l}\text { and ever mindful } \\
\text { of Allah-on these, } \\
\text { both men and } \\
\text { women, Allah will } \\
\text { bestow } \\
\text { forgiveness and a } \\
\text { rich reward. }\end{array}$ & $\begin{array}{l}\text { men and women who } \\
\text { remember God } \\
\text { often_God has } \\
\text { prepared forgiveness } \\
\text { and a rich reward. }\end{array}$ & $\begin{array}{l}\text { and the men who } \\
\text { commemorate God } \\
\text { frequently, and the } \\
\text { commemorating } \\
\text { women; God has } \\
\text { prepared for them a } \\
\text { forgiveness and a } \\
\text { great recompense. }\end{array}$ \\
\hline
\end{tabular}

\section{Discussion}

Like that of the above, the concept of $\boldsymbol{d h i k r}$ or $\boldsymbol{z i k r}$ (ذكر) tends to cause a problem as a theological and technical term because it doesn't have a counterpart in English. The literal, theological and experiential meaning of the word dhikr or $\boldsymbol{z i k r}$ (ذكر) denotes a 'remembering', 'glorifying', and 'praising exercise' repeatedly done without more or less any time or space constraints.

Looking at Yuksel etal.'s, the word 'commemorate' sounds too 'memorial' and limited to a certain contextualised time and space. It also has the connotation of remembering someone/ something that has passed away/gone by, by means of a physical object (monument) or act (moments of silence), which is in odd with Islamic practice, and could be sought as a justification for use of pictures and symbols for worship?. Mentioning 'often' is not enough! Dawood's word 'mindful' is not sufficient either because it doesn't indicate engagement in praising God! Arberry's word 'remember' sounds less problematic whereas Ali's descriptive paraphrase of 'who engage much in God's praise', seems to approximately encompass what is meant by the Arabic concept.

The problem of translating a concept like that doesn't end here but it does only when the alternative English equivalent helps both the translator and the reader to grasp and appreciate the experiential meaning of the concept. To do so, they could look at the concept from a holistic perspective where they could conceptualise, formulate and articulate the concept verbally and even physically in case of performing optional prayers or raising one's hands in 'invocation' or 'supplication'.

The differences in the use of the time adverb as in 'much', 'often', 'ever' 'much' and 'frequently' are also bound to cause confusion to the reader because each version seems to specify the 'howmuchness/quantity of 'dhikr or zikr (ذكر) ' which is not really appropriate because it is not specificed but only by the generic term 'khatheeran' which literally means 'very much'.

Thus in the case of our 'adhakireena Allah katheern wa adhakirat', Ali's translation could be used as a standardized translation because it entails the spiritual and physical meanings of the Arabic concept and a reference to the quantity of 'dhikr or zikr (ذكر) $\quad$ or a naturalization of the terms could be used with an explanatory footnote. Think about the following list of potential equivalent options:

For men and women who engage much in God's praise.

For men and women who remember God very much.

For men and women who are always mindful of Allah.

For men and women who make a lot of mention of God.

For men and women who make dhikr of Allah whenever possible.

For men and women who make many praising exercises of God.

For men and women who exercise the praise of God often?

For men and women who always remember God in supplication

For men and women who very often remember God in invocation. 
It is quite important to point out here that differences in conceptual translation cause not only misconception of Islam and its main principles, but also deprive the translated text of its Arabic original psychological effect as 'The effect of the Quran on Arabic was dramatic, profound, and lasting, to an extent unknown in any other language' (Abdel Haleem, 2011, p62).

The problem of translating a concept like this is also applicable to the rhymingness and rhythemicness carried by the word, the phrase and the whole verse in the Quran which the English versions of the Quran lack most. Marmaduke Pickthall, who translated the Quran in 1930 described the book as 'that inimitable symphony the very sounds of which move men to tears and ecstasy' Ali (1977, xv)

\section{A Proposed Standardised Version of the Translated Texts of the Quran}

Having discussed samples from five versions of translated texts of the Quran and realized that their differences in the translation have given rise not only to loss in translation and mistranslation from a linguistic perspective but also misinterpretation and misrepresentation of the original text, we feel that King Fahd Holy Quran Printing Complex Version of Ali's (1410H/1989G) which is a revised edition of Ali's version (1934) could be taken after some kind of revisiting as a candidate for a potential version for standardisation and authorization. This would help us avoid too many duplication and make it more compatible with the contemporary mind-set of the English Language reader. Look at the amended underlined translation of the above five examples in the following table:

\begin{tabular}{|c|c|c|c|c|}
\hline Example 1:( 24:2) & Example2:(80:33-36) & Example3:( 17:32) & Example4 :( 7:26) & Example5 :( 33:35) \\
\hline $\begin{array}{l}\text { The woman and the } \\
\text { man guilty of } \\
\text { adultery or } \\
\text { fornication, - lash } \\
\text { each of them with a } \\
\text { hundred lashes. }\end{array}$ & $\begin{array}{l}\text { "At length, when } \\
\text { there comes the } \\
\text { Deafening Noise, that } \\
\text { day shall a man flee } \\
\text { from his own brother, } \\
\text { and from his mother } \\
\text { and his father, and } \\
\text { from his wife and his } \\
\text { children," }\end{array}$ & $\begin{array}{l}\text { "Nor come nigh to } \\
\text { adultery or } \\
\text { fornication: for it } \\
\text { is an indecent } \\
\text { (deed) and an evil } \\
\text { way }\end{array}$ & $\begin{array}{l}\text { But the raiment of } \\
\text { God-fearing and } \\
\text { righteousness,- that } \\
\text { is the best. }\end{array}$ & $\begin{array}{l}\text { For men and } \\
\text { women who } \\
\text { engage much in } \\
\text { God's praise,-for } \\
\text { them has God } \\
\text { prepared } \\
\text { forgiveness and } \\
\text { great reward. }\end{array}$ \\
\hline
\end{tabular}

\section{Conclusion and Recommendations}

From the above brief discussion of the samples, we can comfortably conclude that the Quran as a central text tends to cause very serious problems and difficulties for translators in terms of understanding, interpreting and translating certain theological concepts due to the linguistic sophistication of the Arabic language used in the text on the one hand, and the theological, sociocultural, psychological, spiritual and melodic dimensions of the Quranic word.

Thus the above translators seem to have failed to replicate not only the complex web of the stylistic features found in the Quranic text, but also the theologically and culturally loaded concepts carried in the Quranic word. They have also failed in their quest for equivalence or communicative effectiveness. They have violated the loyalty to the source-text principle for the sake of producing a text that works in receptor-genre terms.

Nevertheless, the version authorized by King Fahd Holy Quran Printing Complex of Ali's Translation dated 1410H (1997) seems to be the most appropriate (probably legitimate) amongst the above six translations of the meanings/interpretations of the Quran, although it still needs some kind of revisiting in terms of standardising certain conceptual terms and modernising certain linguistic features in the translated text.

However, standardising a translation of the Holy Quran is a tremendous undertaking which cannot be done at one go. To be practical and get things started, this endeavour must be a phased undertaking. The phases should be prioritised according to levels determined in terms of categories based on the gravity of attested and likely violations due to cultural differences. This would form part of a standardised dictionary. Thus comes the question of what constitutes the other parts as in Islamic terminologies which will of course coincide with elements in the former part. I think in our present state of ecstasy and elevated motivation something, at least in part, should materialize!

Therefore, we would like to make the following recommendations:

$>$ The translation of the Quran should be officially institutionalised and governmentally authorised. An official and authorised institution, for instance, such as that of King Fahd Holy Quran Society should be established to be in charge of this crucial undertaking and be continuously following up readers' reactions, attitudes and feedback to using only one official and authoritative version of the translated text.

A committee of God-fearing Arab and non-Arab Muslim bilingual scholars who hold sound theological beliefs, the publisher and the editors should be involved in the end product of the official and authoritative version of the Quran translation addressed to other non-Arabic speaking Muslim and non-Muslim audience. 
In translating the Quran, the translator should first strive not only to understand its multifaceted meaning, or appreciating its stylistic features, or be able to catch something of the grandeur of the original revelation, but also be able to faithfully render its theological messages without misrepresenting or misinterpreting any of the principal concepts, norms and beliefs implied in them. He or she should have the ability to revel in the rhythm and music of the original text. He should be able to wonder at the meaning obvious or hidden in the Arabic text. He should simply avoid letting his own opinion interpret the text.

$>$ The standardised version of the translated text of the Quran should be suitable in virtually all aspects and not subject to misunderstanding, misconception or distortion of any of the principal theological concepts of the original text and thus maintains the language, spirit and dynamicity of the original as approximate as possible to the Source Language version.

$>$ Standardising should cover not only concepts and main principles but also some aspects of the form where a uniform system, for example, of numbering the verses, Suras divisions of chapters and sections could be maintained to comply with what is universally used in the Arabic copies of the Quran and avoid causing confusion in giving and verifying references.

$>$ Theological terms and sociocultural concepts and principles could be logged in a dictionary and made available for use in translating religious text-types and understanding the translated text of the Quran.

The following is just an example of how to standardise common theological concepts that don't have counterparts in English and may give rise to misrepresenting, misinterpreting and even misconception of certain Islamic concepts and principles:

\begin{tabular}{|c|c|c|}
\hline Standardised Translation & Different Translations in English & Arabic Terms \& Concepts \\
\hline mosque/masjid & $\begin{array}{l}\text { prayer place, Muslim prayer room, multi-faith } \\
\text { prayer room. }\end{array}$ & مسجد/ جامع \\
\hline covenant & $\begin{array}{l}\text { agreement, contract, promise, commitment, } \\
\text { arrangement, treaty, pledge, concord. }\end{array}$ & عهt \\
\hline parable & $\begin{array}{l}\text { story, tale, lesson, fable, allegory, moral tale, } \\
\text { exemplum. }\end{array}$ & قصة \\
\hline grace & $\begin{array}{l}\text { kindness, goodness, favour, goodwill, } \\
\text { generosity, beneficence. }\end{array}$ & كرم/رحمة \\
\hline son of Adam & son of humanity/offspring of humanity & 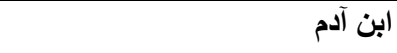 \\
\hline 'taqwa'/god-fearing & $\begin{array}{l}\text { piety, righteousness, awareness of God, } \\
\text { consciousness of God. }\end{array}$ & تقوى \\
\hline 'shura'/consultation & $\begin{array}{l}\text { mutual consultation, counselling, mutual } \\
\text { consent }\end{array}$ & 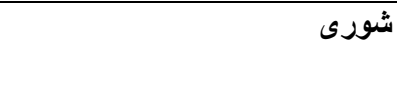 \\
\hline Qibla & 'Restricted Temple', 'prayer direction', & قبلة \\
\hline
\end{tabular}

It is vital to note here that the above table of examples needs to be considered in context. In other words, the standardised translation should be made according to the context the Arabic word is mentioned in as the same word may have different meanings in different contexts. This will help create a standardised but contextualised dictionary of theological terms and concepts of the Quran.

This study seems to have left the following unanswered questions for researchers and translators to contemplate about and perhaps to come up with some possible answers:

1. Can the translator Islamise the English Language in the process of translating the Quran? In other words, can the rules of 'English For Specific Purposes' (ESP) be applied to make English an Islamic Language so that it would help convey the Islamic message specifically more faithfully, more plainly, more economically, more emotively and more effectively?

2. Can the translator transfer the scent of perfume he or she smells from the garden of the Quran to the English readers so that they gladden their nostrils with it? In other words, how can we as translators achieve spiritual and mystic effect in the English version of the translation? 
3. Can the translator reflect the rhythm, music and exalted spirit of the original in the English version of the translation? Can he or she invent a certain mechanism to achieve this seemingly unachievable task?

4. Is it possible for the translator to stop his or her personal views from interfering with the interpretation and then in the translation process of the Quran?

5. Can the translator use British English rather than American English in his or her translation, as linguistically speaking, there seems to be an obvious overlap in the use of American English with that of the British English and this would have some cultural repercussions for the British readers in particular and the European readers in general?

\section{References}

Ali, A.Y. $(1934,1977)$. The Holy Quran: Translation and Commentary, $2^{\text {nd }}$ edition American Trust Publication.

Arberry, A. J. (1955, 1982). The Koran, Oxford University Press.

Abdel-Haleem, M. (2004, 2010). The Quran: A New Translation, Oxford University Press.

Abdel-Haleem, M. (2011). "Translating the Quran”, in Marshall, David (ed.) Communicating the Word: Revelation, Translation, and Interpretation in Christianity and Islam, George Town University Press, Washington, DC

Abdul-Raof, H. (2001a). Quran Translation: Discourse, Texture and Exegesis. In Richmond: Curzon

Abdul-Raof, H. (2005). "Cultural Aspects in Quran Translation”, in Long, Lynne (ed.) Translation and Religion, Topics in Translation, Multilingual Matters LTD.

Al-Shabab, O.S. (1996). Interpretation and the Language of Translation: Creativity and convention in Translation, London, Janus.

Al-Shabab, O.S. (1998). Translating with difference: Theory and Practice, DEBS, Damascus, Syria.

Al-Shabab, O.S. (2008). Linguistic and Cultural Translation in the Translations of the Holy Quran into European Languages. In Scientific Journal of King Faisal University, Vol.9, Issue No. 2

Al-Shabab, O.S. (2008). From Necessity to Infinity: Interpretation in Language and Translation, London, Janus

Al-Shabab, O.S. (2012). Textual Source and Assertion: Sale's Translation of the Holy Quran. In Journal of King Saud University- Languages and Translation, Volume 24, Issue 1 January 2012, Pages 1-21.

Baker, M. (2011). In Other Words: A Coursebook on Translation, $2^{\text {nd }}$ edition. Routledge

Bobzin, H. (1993). Latin Translations of the Koran: A short Overview. In Islam: Zeitschrift fur Geschichte und Kulter des Islamischen Orients 70(2) : 193-206

Dawood, N. J. (1956, 1974). The Koran: Translated with Notes. Penguin Books.

Delisle, Jean (1988). Translation: an Interpretive Approach, Translation of Part 1 of lánalyse du discours comme method de traduction, trans. In Patricia Logan and Monica Careey, Ottawa: University of Ottawa Press (Pages 53-6)

Mustafa, H. (2011). Quran. In Baker, M \& Saldanha, G (ed.) Routledge Encyclopaedia of Translation Studies. $2^{\text {nd }}$ edition, Routledge.

Nide, Eugene A. (2001). Language, Culture and Translating, Shanghai Foreign Language Education Press

Porter, S. E. (2004). The Contemporary English Version and the Ideology of Translation, in Porter, S. E \& Hess R. S (ed.). Translating the Bible: Problems \& Prospects, T \& T Clark International, A Continuum imprint, 2004.

Hatim, B. \& Mason I. (1990). Discourse and the Translator, Longman Group UK Limited

Hermans, Theo, (2011). Hermeneutics, in Baker, M \& Saldanha, G (ed.) Routledge Encyclopaedia of Translation Studies. $2^{\text {nd }}$ edition. Routledge.

KFS (1990). The Holy Quran: English Translation of the Meanings and Commentary, AL-Madinah Al-Munawarah, King Fahd Holy Quran Printing Complex.

Long, L (2001). Translating the Bible: From the seventh to the Seventeenth Century. Aldershot: Ashgate.

O'Donnell, Matthew Brook, (2004) Translation and the Exegetical Process, Using Marks 5.1-10, 'The Binding of the Strong Man', as a Test Case. In Porter, S. E \& Hess R. S (ed.). Translating the Bible: Problems \& Prospects. T \& T Clark International, A Continuum imprint, 2004.

Salama-Carr, M. (2011). Interpretive Approach. In Baker, M \& Saldanha, G (ed.) Routledge Encyclopaedia of Translation Studies. $2^{\text {nd }}$ edition.Routledge.

Saeed, A. (2011). Authority in Quranic Interpretation and Interpretive Communities. In Marshall, David (ed.). Communicating the Word: Revelation, Translation, and Interpretation in Christianity and Islam. George Town University Press, Washington, DC 
Serban, A. (2005). Archaising versus Modernising in English Translations of the Orthodox Liturgy: John Crysostomos in the $20^{\text {th }}$ Century. In Long, Lynne (ed.) Translation and Religion, Topics in Translation, Multilingual Matters LTD

Seleskovitch, D. (1977). Take care of the Sense and the Sounds will Take Care of themselves or Why Interpreting is not Tantamount to Translating Language. The incorporated Linguist 16:27-33.

Versteegh, K. (1991). Greek Translations of the Quran in Christian Polemics (Ninth Century A.D). Zeitschrift der Deutschen Morgenlandischen Gesellschaft 141 (1): 52-68.

Yuksel, E., Al-Shaiban, L. S. \& Schulte-Nafeh, M. (2007, 2010). Quran: A Reformist Translation, Brainbowpress, USA. 